\title{
A Gender Gap in Literacy? Exploring the Affective Im/materiality and "Magic" of Allure with/in a First Grade Classroom
}

Bessie P. Dernikos, Department of Teaching and Learning, Florida Atlantic University, USA

bdernikos@fau.edu

\section{Abstract}

Within this article, I think with (Jackson \& Mazzei, 2012) posthumanist theories of affect and assemblage (Deleuze \& Guattari, 1987) to argue that literacy learning within a first grade classroom (NYC) involved allure (Thrift, 2008), or more-than-human technologies of public intimacy that were affectively contagious and seemed to take on a life of their own. By doing so, I contribute a new dimension to literacy-gender debates by exploring how the im/material practices of allure emerge to produce entanglement, bliss, and even violence. While male students' entangled reading practices disrupted popular assumptions of "failing boys," thereby making new gendered and literate subjectivities possible, these practices, at times, further reinforced rigid heteronormativities. Ultimately, attending to literacy learning as alluring invites more ethically response-able (Barad, 2007) considerations that take seriously how the forces of gender, sexuality, and race work to animate/contain bodies, spaces, and things, as well as shape the un/making of students as "successfully literate."

Keywords: literacies, affect, allure, posthumanism, im/materiality, magic, intimacy, gender/sexuality, race, literacy gender gap, "boy problem" 
Readers Workshop in session, Ms. Rizzo's first grade classroom (New York City, USA) ${ }^{l}$

Peter: ...I really like this book (Snow White).

Miss Bessie: I remember you saying you wouldn't read a book like this one (a "girls' book"). You changed your mind?

Peter: ...Yeah, I like it because it's London's (points to Snow White). She's nice and kind and beautiful.... Just like London.

$*$

In the United States, Australia, Canada, and the United Kingdom, the general trend within literacy and gender debates has been to construct girls as successful literacy learners and boys as "literacy failures" (Skelton \& Francis, 2011, p. 459). Since the late 1990s, discourses of successful girls and failing boys have circulated within media, popular psychology, and educational research to suggest that, largely due to second-wave feminists' efforts to equalize social, educational, and employment experiences for females, the future has become female (McRobbie, 2009; Ringrose, 2013). Males are, in turn, positioned as the new disadvantaged-i.e., the underachieving "losers" of feminism (Martino, 2008; McRobbie, 2009; Ramazanoglu with Holland, 2002; Ringrose, 2013; Skelton \& Francis, 2009, 2011).

Over the years, this "boy problem" (Bissell-Brown, 1990) has become synonymous with a "crisis" in literacy (Weaver-Hightower, 2003). Yet, it is steeped in a kind of gender essentialism that homogenously pits boys and girls against one another (Renold, 2004) in order to fuel a media driven panic logic that problematically marks the figure of the underachieving male as both the poster boy for "literacy letdown" (Harris, 2015) and the victim of reverse sexism (see Lucey \& Walkerdine, 2000; Martino, 2008; Niccolini, Dernikos, Lesko, \& McCall, 2019; Ringrose, 2013). In fact, as many educational scholars have argued, the alleged "literacy gender gap" (Francis \& Skelton, 2005; Lucey \& Walkerdine, 2000; Skelton \& Francis, 2009; Weaver-Hightower, 2003) is less about actual literacy achievement and more about "the multiplicity of masculinities that compete and overlap in school settings" (Renold, 2004, p. 247), or the ability of young boys to do gender "right" (see e.g. Davies, 1997; Dutro, 2001/2002, 2003; Skelton \& Francis, 2011; Smith, 2004). Indeed, a number of studies have examined how some boys actively resist the category of "good reader" if such a label works to discursively position them as feminine or gay (Connell, 1996; Davies, 1997; Frank et al. 2003; Mac an Ghaill, 1994; Martino, 2008; Renold, 2004). At the same time, studies (see e.g. Dutro, 2003; Skelton \& Francis, 2011) have also shown how a kind of social status predicated on hegemonic masculinity (Connell, 1996) may work to protect popular, "sporty" boys from being called gay, wimpish, or girly, thereby enabling them to freely participate in "feminized" classroom activities (e.g., reading books, expressing their feelings), without fear of ridicule.

\footnotetext{
${ }^{1}$ This study takes place within Ms. Rizzo's first grade classroom (NYC). Peter, a young African American boy, and London, a young Hispanic girl, are both Ms. Rizzo's students.
} 
Collectively, this research seeks to examine the oppressive ways in which hegemonic masculinities are constructed and performed, particularly by boys who fail to consistently embody dominant forms of masculinity (Renold, 2004). Yet, much of this work "has been developed from a logocentric, aspatial perspective" (Leander et al., 2010, p. 337) that largely ignores how particular social bodies (e.g. spaces) affectively intra-act (Barad, 2007) to de/re/territorialize (Deleuze \& Guattari, 1987) boys' literate identities (for discussions on gender, education, posthumanism, and school success see e.g. Lenz Taguchi \& Palmer, 2014; Pomerantz \& Raby, 2018; Taylor, 2013). For instance, as both Dutro (2003) and Skelton and Francis (2011) note, "successfully" literate boys who appropriated hegemonic discourses were still subjected to name-calling/teasing when around other bodies in other spaces. To date, then, there has been scant research within the field of literacy education exploring young children's affective responses to texts (see Dernikos, 2018; Leander \& Boldt, 2013; Lenters, 2016) and the ways that a body-as an active agent-possesses force, i.e. the power to affect other social bodies (e.g., spaces, texts, discourses of gender) and what those bodies can do.

In the case of Peter (a 7 year old African American boy), he often did not read during Readers Workshop time and instead opted to flex his muscles, while slouching in his chair, and say such things as, "No way I'm reading that. . . because I'm a man." What I would like to open up here is the possibility that Peter's non-reading of particular texts is not simply his choice but involves complex configurations that move with Peter's body in ways that facilitate his becoming a "struggling reader" (Dernikos, 2018). As Renold (2004) argues, when focusing on the "underachieving boy" we must attend to the forces of gender and heterosexuality that flow into classroom spaces, working to influence the way young males, especially black males (Dernikos, 2018; Kirkland \& Jackson, 2009), perform their gendered identities.

At the same time, I would also like to suggest that such forces are far from predictable. As the above vignette illustrates, Snow White has unexpectedly morphed into something other than a mere 'girls' book' here-as now an agentive "thing" attached to London's very body. And, while Peter's new interest in Snow White might very well be a way to seek out London's attention, it might also be read as an attempt to safeguard Peter's desire to read a book coded as feminine. Interestingly enough, Peter's actions functioned as a kind of contagion, where other boys soon began to read London's favorite books, despite the fact that such books were initially denigrated.

Within this article, I think with (Jackson \& Mazzei, 2012) posthumanist theories of affect and assemblage (Deleuze \& Guattari, 1987; Seigworth \& Gregg, 2010) to argue that literacy learning within Ms. Rizzo's first grade classroom (NYC) involved allure (Thrift, 2008), or "a series of 'magical' technologies of public intimacy" (Thrift, 2008, p. 9)-magical in the sense that they were affectively contagious and seemed to take on a life of their own, "part human, part something else" (p. 14). By doing so, I contribute a new dimension to literacy-gender debates by exploring how the $\mathrm{im} /$ material practices of allure emerge to produce entanglement, bliss, and even violence - e.g., Peter and the other boys only now seem able to 'like' 'girls' books' without consequence because of their heterosexual desire for London. In the end, it is my hope that attending to literacy learning as alluring invites more ethically response-able (Barad, 2007) 
A Gender Gap in Literacy? Exploring.. 333

considerations that take seriously how the forces of gender, sexuality, and race work to animate/contain bodies, spaces, and things, as well as shape the un/making of students as "successfully literate."

\section{Affect}

Affect is rangy, capacious, and somewhat difficult to pin down (Seigworth, 2017). As no one theory of affect exists, scholars have often taken affect up in subtle yet dramatically distinct ways, for example as atmospheres (Anderson, 2014; Brennan, 2004), charges (Stewart, 2007), emotions (Ahmed, 2011), energies (Brennan, 2004), forces (Seigworth \& Gregg, 2010), or intensities (Deleuze \& Guattari, 1987) (see Dernikos et al., 2020 for a review of this literature; Niccolini et al., 2019; Niccolini, 2016a). Despite these various conceptualizations, the recent "affective turn" within literacy (see e.g. Dernikos, 2018; Jones \& Spector, 2017; Leander \& Boldt, 2013; Leander \& Ehret, 2019; Lemieux, in press; Lenters, 2016; Niccolini, 2016b; Thiel, 2015) has enabled educators to reimagine the subject as a more-than-human configuration of entities or force-relations, whereby the "self" is thought to extend into a dynamic assemblage of signs, objects, bodies, texts, languages, discourses, emotions, and so forth (Deleuze \& Guattari, 1987). Each entity within the assemblage acts on the subject-albeit not equally-and has some form of distributive agency (Bennett, 2010), which disrupts the humanist notion of individual autonomy/will as well as highlights the openness, interconnectedness, and vulnerability of bodies (Dernikos, 2018; Niccolini, 2016a; Seigworth \& Gregg, 2010).

\section{Literacy and Gender as Affective Encounters}

Theoretically, affect is useful for rethinking and further problematizing the notion of a gender gap in literacy. While poststructural and queer theories of the subject have greatly contributed to re/conceptualizations of gender and literate identities as relational, multiple, processual, as well as historically and socially located (Mac an Ghaill, 1994; Renold, 2004), the attention to bodies in space often "collapses in favor of a temporal emphasis on gender as 'stylized repetition' and 'social temporality"' (Sedgwick, 2003, p. 9). As such, these theories do not quite attend to the subject as an assemblage of material, discursive, and affective configurations (e.g., of human bodies, texts, spaces, desires) always produced in relation to other bodies, spaces, and things (Mulcahy, 2012; Renold \& Mellor, 2013).

Affect signals a re/turning to, building upon, and complicating of such theoretical accomplishments and analyses (Dernikos et al., 2020; see also Hughes \& Lury, 2013). A re/turn to affect not only "take[s] embodiment seriously [but also].... emphasize[s] the entangled nature of events and the ways in which multiple figurations interact to produce the sites, scenes" (Wetherell, 2013, p. 263), and markedly uneven textures of social life. In this way, affect theories enable a view of bodies as im/materialdiscursive phenomena (Barad, 2007; Blackman, 2012) that can never be wholly captured by static, linguistic codes (see Grosz, 1993; Puar, 2011), such as "good reader" or "underachieving boy." Bodily categories (e.g., gender, sexuality, race, class, ethnicity, and ability) themselves are conceptualized as dynamically performed "events, actions, and encounters between [human and nonhuman] bodies" 
(Puar, 2011, p. 58). Such categories do not determine who a subject is (e.g., the concepts of female and feminine might easily come to "stick" to a male body as much as a female one), but rather highlight the dynamic processes at work to code or territorialize (Deleuze \& Guattari, 1987) our desires, relations, and connections to other social bodies within complex affective assemblages that are always "partial, dispersed, fragile, tentative" (Mulcahy, 2012, p. 12).

Re/turning to affect offers a means of sensing how learning to read is always a dynamic, shifting, and unstable process entangled with/in relational forces (Leander \& Ehret, 2019), which are all at once promising and/or threatening (Dernikos, 2018; Dernikos \& Thiel, 2019). In other words, the relational entanglements of gender, sexuality, race, and so on, not only shape what counts as literacy but also "proper" humanity (Chen, 2012), all the while making particular bodies vulnerable to processes of re/territorialization. For example, in one moment Peter becomes a "struggling reader" (as described by his teacher and classmates) who refuses to read 'girls' books' and, in another, a "good reader" who chooses "appropriately" leveled texts across different genres (here, London's fairytale book). Thus, a "body's function or potential or 'meaning' becomes entirely dependent on which other bodies. . . it forms an [affective] assemblage with" (Malins, 2004, p. 85, as cited in Ringrose, 2011, p. 601).

\section{Allure as an Affective Force}

Although allure is generally defined as a "quality of being powerfully and mysteriously attractive or fascinating" (Oxford Dictionaries, n.d.), Thrift further reimagines it as an affective force intimately connecting people and things in "magical" ways. According to Thrift (2008), there is an aesthetic quality to allure as it affectively circulates through institutions of public intimacy:

Aesthetics is the way we communicate through the senses. It is the act of creating reactions without words, through the look and feel of people, places, and things... it is both moved and moving...It is a force that generates sensory and emotional gratification. It is a force that produces shared capacity and commonality. It is a force that produces enjoyment. It is a force that, though cross-cut by all kinds of impulses, has its own intrinsic value. (Postrel, 2003, p. 6, as cited in Thrift, 2008, p. 10)

Such a force invites us to consider how humans and nonhumans have the power to not only affect one another, but also captivate. There is, therefore, a magical quality to allure, as it enables us to become intimately connected to that which enchants us, thereby intensifying our sensory and emotional attachments to other people and things. As Thrift notes, people are not autonomous entities; rather, they extend into 'others,' thereby 'blur[ring] the boundary between person and thing in order to produce greater captivation.... persons are 'fractal', able to incorporate others and parts of others" ( $p$. 10). As a force-relation, then, allure has an affective economy or value to it (see also Ahmed, 2004 for affective economies), as it (momentarily) binds humans and nonhumans together in emotional ways that are often gratifying. 
Within this article, I both draw and build upon aspects of allure to highlight how literacy learning involves affective fields of intimacy that captivate subjects (such as Peter), namely in "sticky," contagious ways that are all at once promising and threatening (see Stewart, 2007 for affect's promise and threat). At once material and immaterial, allure is an affective force defined by its capacity to affect and to be affected, yet often in ways that are unpredictable. As Thrift warns, allure can also be "a deceptive or bewitching beauty or charm" (p. 14) casting a kind of spell that may lead to "unobtainable realities" (p. 12). As I will later discuss, allure's threat may serve to symbolically harm young boys who potentially appropriate hegemonic discourses to safeguard their desires-even as the affective attachments they are entangled with/in simultaneously work to produce bliss.

\section{Contextualizing the Research}

Ms. Rizzo's classroom, part of a Title 1 public elementary school, was situated in an economically and culturally diverse neighborhood in New York City. The students featured in this article identified as African American (Alim, Beth, Dylan, Peter, Natasha, Dan), Hispanic (London, Austin), and White (Andre, Tom). Ms. Rizzo, who had been teaching for 5 years, identified as Hispanic. Ms. Rizzo, in line with the school's mandated literacy curriculum, implemented a balanced approach to literacy learning based on the Core Knowledge Language Arts curriculum, the Teachers College Reading and Writing workshop model, and the Common Core State Standards for English Language Arts and Literacy (see Dernikos, 2018).

According to Ms. Rizzo, successful literacy students were expected to climb up text levels, read across a variety of genres, apply workshop-model strategies while reading/writing independently, accurately answer Core Knowledge read-aloud questions, and actively take control of their bodies in order to efficiently execute a number of controlled gestures (e.g., putting their thumb up in the air to signal they liked a book). Although Ms. Rizzo strove to adhere to school mandates, she at times expressed concerns, specifically in relation to the Core Knowledge read-aloud series, which primarily privileged Western history, literature and culture-the so-called canon of cultural literacy. While Ms. Rizzo and I experienced some difficulty inviting student talk on the rug in relation to students' feelings about given texts, especially those they had difficulty relating/connecting to, I did not encounter much trouble in getting students to open up to me one-on-one or in small groups. Though I cannot say for sure why that was, I do believe that my vulnerability may have helped put the students at ease. I readily shared with them my stories, experiences, and childhood struggles growing up as a Greek American girl. Many students, for instance, were surprised to hear that my parents were Greek immigrants and that I (like some of them) had entered kindergarten not speaking English. I also tried, as best I could, to give students space to share their own stories and to respond freely to situations-to cry, laugh, hug and even say "inappropriate" things (Dernikos, 2018). 


\section{Thinking with "Data": Non-representational Research}

Over the course of 6 months (January-June 2014), I visited Ms. Rizzo's classroom two-five times per week during the 90-minute literacy block, which consisted of reading/writing mini-lessons, shared reading/writing, read-alouds, and independent reading/writing time. My interest in understanding literacy learning as transcorporeal (or more-than-human) social encounters led me to adopt nonrepresentational research techniques (Leander \& Boldt, 2013; Vannini, 2015) in order to think with (Jackson \& Mazzei, 2012) "data," collected here through participant observations, fieldnotes/writing, and informal student and teacher interviews. Impossible to fully capture with words (Jackson \& Mazzei, 2012), thinking with data is an embodied engagement that involves "poring over the data, annotating, describing, linking, bringing theory to bear, recalling what others have written, and seeing things from different angles" (MacLure, 2013, p. 174). It is a lively process that opens us up to surprise, multiplicity, and even wonder (MacLure, 2013). According to Niccolini (2016b), this type of analysis concerns itself less with representational fidelity and more with working with data to disrupt our usual thinking: "to enliven rather than report, to render rather than represent, to resonate rather than validate, to rupture and reimagine rather than to faithfully describe" (Vannini, 2015, p. 15, as cited in Niccolini, 2016b, p. 7; see also Dernikos, 2018).

The classroom moments I have chosen to include here, thus, offer a "strategic sketch," or "an invitation to an alternative means of experiencing data-to think and feel with the possibilities of the data and not 'over' them toward conclusion" (Leander \& Boldt, 2013, p. 26). As I imagine them, strategic sketches are provocations (see also Wargo, 2018) that invite us to experience literacy practices as more-than-human scenes of entanglement. Such provocations create a sense of liveliness that enables us to consider not what a particular scene "means" within a representational frame but, rather, what it may have to offer once we "plug into" (Jackson \& Mazzei, 2012) and play with different theories. In this way, I am not using data to prove that these moments within Ms. Rizzo's classroom definitively represent or signify a singular reality. Rather, by "reading-the-data-while-thinking-the-theory" (Jackson \& Mazzei, 2012, p. 4), I am attuning myself to the concept of literacies as affective and then, more specifically, alluring. I do so in order to explore what emergent possibilities and threats exist for young boys and girls, both as literacy learners and as human beings. My hope is to create a sense of wonder-a narrative thread that leaves an impression and even inspires social change (Vannini, 2015) so that we may not only begin to rethink this notion of a literacy gender gap favoring girls but also disrupt the idea of boys as the underachieving "losers" of feminism(s). By focusing on the emergence of students' more-than-human encounters and the ongoing capacities of bodies to intimately affect and be affected, allure offers new and different possibilities for understanding and politicizing social understandings of what counts as literacy and who counts as successfully literate (see Kinnunen \& Kolehmainen, 2018 for discussion of affect and the social).

In the sections that follow, I begin by first "sketching" out how the idea of 'girls' books' and 'boys' books' initially circulated throughout Ms. Rizzo's first grade classroom in ways that were rather risky for 
particular students, namely boys of color. Within these scenes, I primarily draw upon a Deleuzoguattarian conception of affect to map out how texts, bodies, spaces, desires (among other things) affectively assemble to produce students as "un/successful" readers and gendered subjects. I then sketch out two additional scenes to further explore the concept of literacy learning as alluring. The first revisits the moment with Peter and his growing fascination with London's Snow White book. The second shows how this moment set off lines of flight (Deleuze \& Guattari, 1987) for other boys, making it possible for them to now read 'girls' books' out in the open-yet not without cost. To be clear, within the initial two scenes detailing the students' feelings around girls' and boys' books, I have deliberately chosen not to think with allure in order to highlight: (1) my desire to tell a story in ways that make the data "come to life, in allowing them to take on new and unpredictable meanings" (Vannini, 2015, p. $119) ;(2)$ the surprise and wonder I initially experienced when Peter and the other boys began to openly read 'girls' books' - i.e., these moments only became more intelligible to me after I "plugged" the data into allure; and (3) how thinking with a Deleuzoguattarian theory of affect/assemblage alongside allure later enabled me to sense the emergence of different conceptualizations of gender and literacy. I conclude by exploring the ethical possibilities for thinking of literacy learning as alluring. Ultimately, I invite educators to consider how an attention to allure opens up spaces to disrupt the normalizing fictions that have come to dominate literacy-gender debates, in order to create new narratives.

\section{'It Don't Matter If It's a Girls' Book, Right?’}

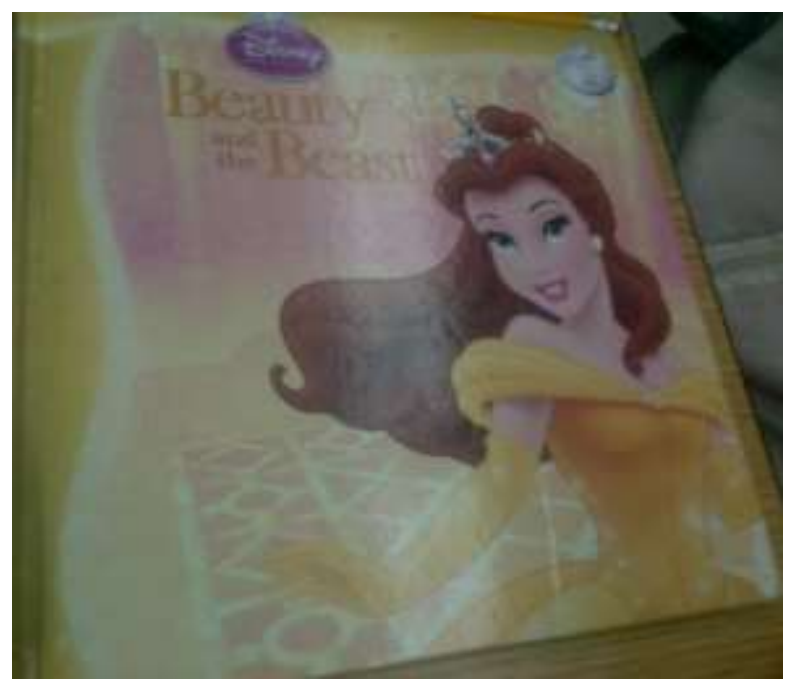

Figure 1. Beauty and the Beast: A 'girls' book'?

For quite some time, it appeared that the children in Ms. Rizzo's first grade class had internalized normative gender discourses and the "idea of [a] dualistic oppositional maleness and femaleness" (Davies, 1997, p. 231), as many often told me such things as boys and girls are "different" and like "different things," causing certain books to be "for girls" while others were only "for boys." In fact, the 
term girly and concept for girls surfaced and circulated throughout a number of classroom spaces, in ways that initially suggested that it was somehow taboo or wrong for boys to like 'girls' books':

Alim: (reading Beauty and the Beast) It don't matter if it's a girls' book, right?

Miss Bessie: What's a girls' book?

Alim: (points to the cover) See, a girl. . . on the cover.

Miss Bessie: So, what makes it a girls' book is that you see a girl on the cover?

Alim: (shakes his head up and down) It don't say girls' book but there's no boy. (Dylan shakes his head from left to right)

Miss Bessie: What do you think, Dylan?

Dylan: I think, um, I think a book for boys and girls.

Alim: No. It's London's. London is a girl. And, girls like love and girl stuff. Boys don't. See (points to Beauty on the cover), Beauty is a princess.

Miss Bessie: What's girl stuff?

Alim: That be... um ... stuff for girls. .. stuff girls like.

Miss Bessie: What kind of stuff do girls like?

Alim: Like princesses, and like... happily after ever.

Dylan: Happily ever after.

Alim: That's what I said.

According to Alim, even though a book may not specifically say 'girls' book,' there are particular markers that indicate texts are girly or 'for girls.' First, a 'girls' book' has a girl on the cover-not a boy-and the story itself revolves around 'girl stuff,' such as fairytale princesses who fall in love with princes and live 'happily ever after.' Alim, therefore, judges the book as a thing for girls based on the sex of the main character (Beauty, on the cover) and the theme of romance or love (see also Dutro, 2003). Moreover, as Alim notes, this particular book belongs to London, a female classmate, suggesting that this thing (Beauty and the Beast) cannot be detached or made distinct from London's physical body.

London was the quintessential docile "good girl" (also noted by Austin) who was generally polite, wellbehaved, hard-working and diligent, while still passive (see Harris, 2004; Walkerdine, 1990). And, she actively performed girl by subjecting herself "to those technologies of the self that are constitutive of the spectacularly feminine" (McRobbie, 2009, p. 60), for example, applying lip gloss, wearing pink skirts and tops, fastening colorful bows or ribbons in her hair. She loved fairytales and princess books, so much so that she donated several of her own books to the classroom for other students to enjoy. Yet, for Alim, such enjoyment was risky. He seems to assume that biology (e.g. sex = male) alone determines who boys and girls are socially (e.g. boy = masculine) (Davies, 1997). An effect of his assumption is that Alim questions whether or not it matters that he, a boy, enjoys reading a 'girls' book'-a book potentially not meant for his sex/gender. In some sense, then, Alim worries that his desire may be indicative of an improper male pleasure (Jones, 2001). 
While Dylan comforts Alim by stating that Beauty and the Beast is a book 'for boys and girls,' his actions suggest otherwise.

Miss Bessie: Dylan, would you ever read this book?

Dylan: No.

Miss Bessie: You wouldn't read it?

Dylan: Well. . (looks around) I already did. (after a moment) I mean didn't.

Alim: I would. It's my third time. I like this part (shows fighting scene).

Dylan: Me too! That's the part Gaston fights the Beast.

Miss Bessie: But you didn't read it? (Dylan is silent)

Dylan: No, not for me. But for Alim it's okay. It's okay to read a girls' book.

Miss Bessie: But don't you have to read some of these kinds of books? What if they were in your blue [book] bin?

Dylan: I just put it back here. I just keep it in my seat-sack and don't read it.

Initially, Dylan admitted to reading Beauty and the Beast ('I already did'), but after a moment, changed his mind ('I mean didn' $t$ '). And although he claimed he had never read this book, he seemed to know the storyline (that a fight ensues between two male characters, namely Gaston and the Beast) and connect to Alim's favorite part ('Me too!'). Interestingly enough, Alim's favorite part involves two male characters behaving in stereotypically masculine ways (e.g., displaying aggression, fighting), suggesting that there might be themes other than romance circulating within this text. Yet, Dylan still insists that this text is a 'girls' book' and, as such, 'not for him.' Thus, he does not want this "feminine" thing to be attached to his "male" body, despite any pleasure it might give him. So, while it is 'okay' for Alim to read a 'girls' book,' it appears inappropriate for Dylan.

Multiple desires, then, circulate around and through Dylan's body: a desire to support his friend Alim, to momentarily connect to the "feminine" (a 'girls' book'), and to regulate his desires by refusing that which is constituted as feminine (e.g., by not reading 'girls books', even if required, and by hiding such texts in his seat-sack). What this scene illustrates is that students' desires are relational encounters (Deleuze \& Guattari, 1987; McWilliam, 1996). As such, textual "choices" are never disembodied from other bodies (e.g., Alim's body next to Dylan's body), other things (e.g., this particular text coded as girly), and other forces (e.g. heteronormativity) that potentially impact male students' becomings as they successfully participate (with potential psychic and emotional costs) or withdraw (with potential schooling consequences) from classroom literacy events. It is important to note that Alim and Dylan were both considered to be "struggling" for their inability to read at or above grade-level expectations. Thus, a refusal to read any books has specific consequences for them. For instance, Dylan's desire to disregard classroom reading expectations in order to avoid a girly book often served to further reinforce his position as a "struggling reader." Even though Dylan did seem to be reading such texts during independent reading time, he often did so furtively, which may explain why Ms. Rizzo often read his actions as off-task, irrational, and inefficient. For that reason, she often reminded Dylan to "get busy," "sit ready," "start reading," "review your reading goals," "focus," and "stop being silly," while at the 
same time wondering why he seldom completed required written responses after reading (in his Reader Response notebook).

What I would like to suggest here is that, while reading specific leveled and "classic" fairytale texts may count as a successful literacy behavior within this first grade class, this intra-action may also threaten Dylan's capacity to function as a "proper" black male (see Dernikos, 2018; Kirkland \& Jackson, 2009). According to Kirkland and Jackson (2009), "canonical" texts, such as Beauty and the Beast, often reinforce hegemonic ideologies of whiteness, which work to influence the way young males, especially black males, perform their gendered identities, for example through braggadocio, fashion, language, sports, non-studiousness and "having a laugh" (see also Renold, 2004, p. 248). They argue that resistance to reading such texts is in fact a sophisticated way for black boys to assert their manhood in a world "painted white" (Muñoz, 2000, p. 68)-a world that often dehumanizes them. Affective encounters, then, are an entanglement of mixed forces, desires, and things that have the capacity to mark a body's belonging to a social world (Seigworth \& Gregg, 2010)-for Dylan, a social world where he is considered "a man" or "proper" black boy-and/or non-belonging_Dylan's labeling as a "struggling reader."

\section{'Girls' Books': Attaching to Goodness}

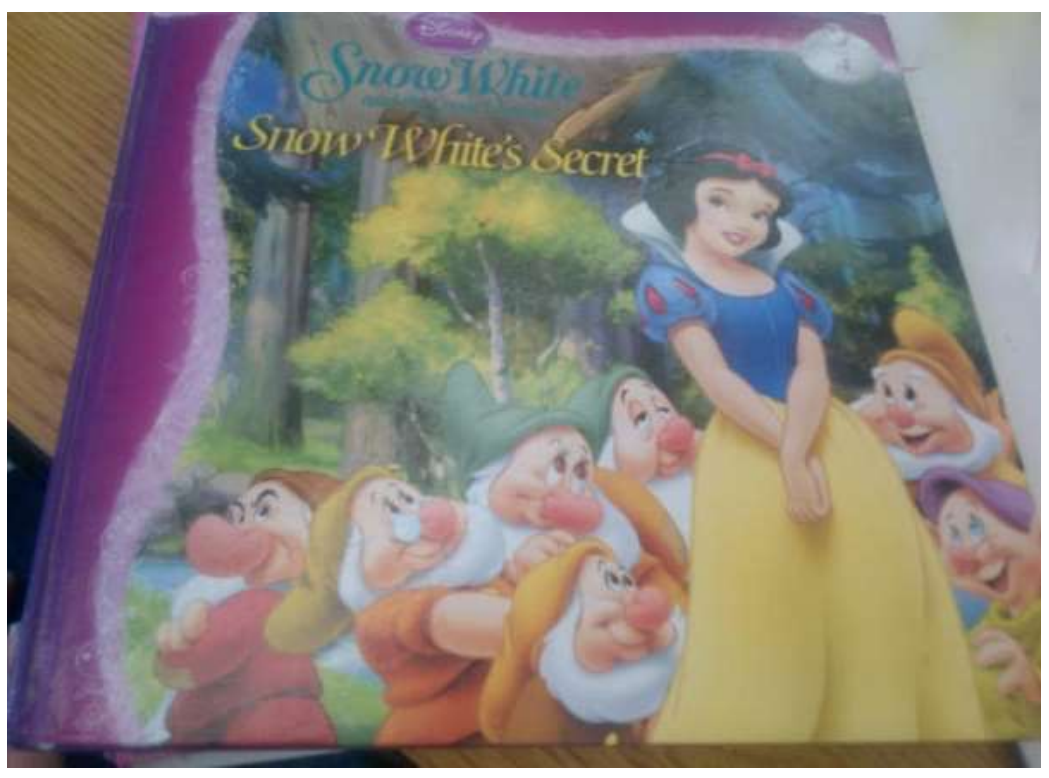

Figure 2. Snow White: One of London's donated books

Within Ms. Rizzo's classroom, the making of gendered literate bodies functioned through attachments to not only particular things (associated with the coding of books as masculine or feminine) but also particular virtues, where a "good reader" presumably chose "good" books with "good" moral messages.

Peter: Um, is this London's book? (pointing to Snow White text, see Figure 2) 
Miss Bessie: Yes, she gave it to us. She donated the books.

Peter: Ugh, why did she give these ones?

Miss Bessie: Because they used to be her books, and she gave them to the class.

Natasha: I like them, um princess books, and I really like what they say-you know, have dreams, follow your dreams, never give up.

Miss Bessie: Okay, so do you like books with certain messages?

Natasha: Like positive things to give you a goal in life, things to help you out in life, I really like those kinds of books, like Disney books. . . because they have a good message.

Austin: Yeah, but boys' books are cool.

Peter: Yeah.

Austin: Look, guns and swords! (shows us pages from Danny and the Dinosaur book, see Figure 3).

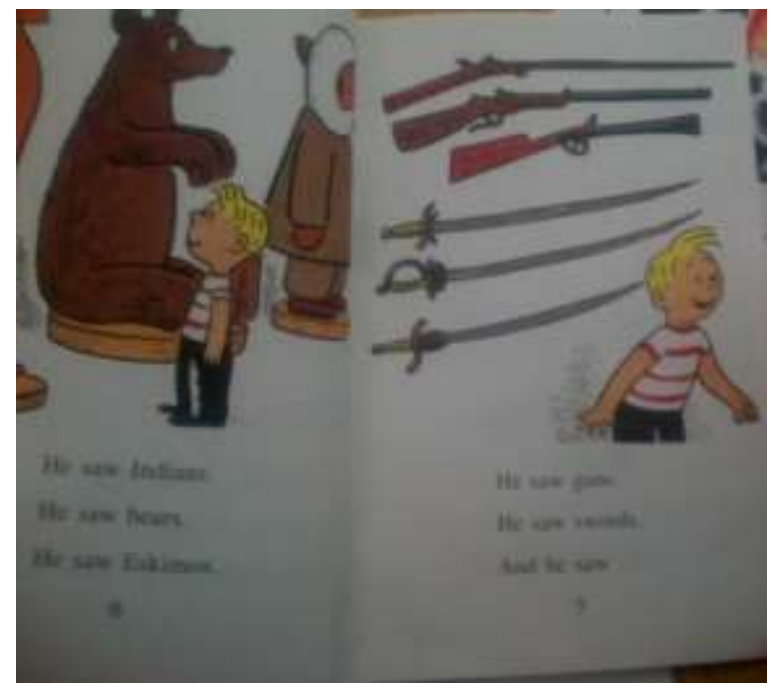

Figure 3. Danny and the Dinosaur as a 'boys' book'

Natasha: That's not a good book-not good for kids.

Miss Bessie: What makes you think so?

Natasha: I don't think it's good for kids to see guns at this age. I don't think it's nice and appropriate at this age. If a kid sees a gun in a book or something, they might think it's nice and then they grow up with bad thoughts and maybe end up in jail or something.

Miss Bessie: So, are you saying that books shape our thoughts and ideas? (Natasha nods)

Peter: Eew girls' books. (pointing again to Snow White)

Natasha: Girls' books have good messages.

Peter: Like, what's good about this? (points to Beauty and the Beast, see Figure 1)

Natasha: The good message in this one is when you fall in love, you don't really know, until you really do. Yep. True love...

Peter: No way l'm reading that. 
Miss Bessie: Why not?

Peter: Because I'm a man. (flexes his bicep muscles, kids laugh)

Andre: A good reader has to read. .. maybe don't like.

Miss Bessie: Can you say more, Andre?

Andre: I no like these (points to Snow White and Beauty and the Beast books), but a good reader read all books.

Natasha: They never give up! They can achieve anything!

Here, Peter's aversion to 'girls' books' resonated in his bodily utterances (ugh, eew) and physical gesture (pointing), which directed attention towards London's books as an object of disdain, something 'a [real] man' would avoid. It seems, then, that Peter's masculinity extends relationally into these objectsthings which somehow threaten his capacity to "do [proper] boy" (Renold, 2004; Renold \& Mellor, 2013). This vignette highlights that there were multiple masculinities present within Ms. Rizzo's class, some more privileged than others. For example, unlike Andre who performed his masculinity in less dominant ways, e.g., openly reading fairytales or 'girls' books', Peter performed his masculinity in more hegemonic ways, e.g., here flexing his muscles in an attempt to display his body as not-feminine (Messner, 2002). As Peter's talk and actions suggest, boys may face pressure from their male peers to be the opposite of girls (i.e. "masculine" or 'a man') and, as such, they are made to feel shame ('no way I'm reading that') by their juxtaposition to or association with girls and feminine things (Connell, 1996).

While London's texts next to Peter's male body potentially signified a lack of masculinity, next to Natasha's female body, these texts emitted sensations of "girl power" (Griffin, 2004; Taft, 2004). Since London's books have been coded as feminine, Natasha too imagines Disney princess books to be 'girls' books' with 'good messages' that instill girls with 'positive things.' According to Natasha, such messages suggest that girls are powerful subjects who can follow their dreams and achieve their goals. In short, girls "can do anything" (Harris, 2004, p. 13) ('They never give up! They can achieve anything!'). At the same time, these fairytale texts (e.g., Snow White, Beauty and the Beast, Cinderella, Sleeping Beauty) also seem to privilege "good" white female heroines who are outwardly feminine in appearance (e.g., wearing make-up and dresses) and heterosexual (desiring to marry a prince) (see Dernikos, 2018). For that reason, Natasha embraces more traditional messages of emphasized femininity (Connell \& Messerschmidt, 2005) by suggesting that 'true love' between a man and a woman not only exists but is also a good thing - a thing that is 'nice and appropriate.' What becomes desirable and proper for girls, then, is to believe that they (with enough perseverance) can be successful students with successful futures-girls who don't necessarily need a man, but seem to want one nevertheless (Harris, 2004).

While girl power discourses give girls a feeling of power and confidence, they, at the same time, discount "the material and discursive forces shaping identity and the ways that these gendered, raced, classed, and sexualized identities may give girls privileges or pose challenges" (Taft, 2004, p. 73). Though the subject of race rarely came up in student talk on the rug, privately Natasha did reference the fact that she was black and one of her favorite Disney princesses (Cinderella) was white, stating, "She's not the same color as me, so it's kind of shaky. Sometimes I'm asleep, I think, I'm not her." When I asked 
Natasha to elaborate, she could not (or would not), yet her words suggest that such messages did not attach to all girls' bodies similarly, thereby intimately impacting girls of color in distinct ways.

\section{'Boys' Books': 'That's Not a Good Book'?}

Conversely, 'boys' books' were constructed in opposition to 'girls' books,' and usually revolved around a central male character (e.g., Danny in Austin's book, see Figure 3). In Austin's specific book, images of violence (guns, swords) circulate, which Natasha argues may result in a kind of "badness": e.g., having bad thoughts, doing bad things, and possibly experiencing jail time. However, being good has different ramifications for girls than for boys, as dominant heteronormative discourses tend to position girls as "docile good girls" (Harris, 2004, p. 19) and boys as naughty-where, as Austin indicates, naughty becomes constructed as cool (Walkerdine, 1990). Yet, as some researchers suggest (e.g. Ferguson 2002; Kirkland \& Jackson, 2009), "coolness," while often read as "off task" or "troublemaking" behavior, may be one possible way black boys construct and affirm their sense of self within racialized school spaces which by and large serve to dehumanize them. Interestingly, Andre, who is a white male, states that a 'good reader' has to read all kinds of books, even those deemed undesirable for boys, here 'girls' books.' Andre, unlike Peter and Austin, had just come to America from Russia and, while a strong student, was still unfamiliar with a number of social norms. So, when Andre behaved in ways that appeared girly (for example, reading princess books), the other more hegemonically masculine boys often stated, "Oh, he doesn't know" (Peter). But, perhaps because Andre moved with assemblages in different ways (white male, Russian ethnicity, English language learner, high-level reader), he could embrace these texts in a way that Peter (black male, "struggling reader," popular) and other hegemonically masculine boys could not. The heterosexual matrix, then, flowed through bodies and things in different ways, enabling students to relationally connect to and/or reject particular ideas, texts, and literacy practices.

\section{Literacy Learning as Alluring: The Becoming of 'Girls' Books'}

For a while, it seemed to me that female students in Ms. Rizzo's class could choose any book to read without fear of peer ridicule, while many of the boys could not. In her study of fifth graders' gendered book choices, Dutro (2001/2002) argues that:

The classroom can be a space where those lines that 'indicate a limit or extent' can be crossed, interrogated, and ultimately blurred. We can create spaces where a 5 year-old-boy can pull Beauty and the Beast off the shelf and leave the library with a smile on his face. (p. 384)

Dutro asserts that gender has boundaries that can be 'crossed,' 'interrogated,' and 'blurred,' specifically through critical literacy engagements with text. Building on Dutro's call to engage in literacy practices that seek to disrupt oppressive gender discourses, I wish to suggest that such a disruption involves a rethinking of gender, sexuality, and space as animate-as setting in motion the circulation of affective forces that are alluring. 
As I have explored in the above vignettes, gender and sexuality do not flow linearly throughout some monolithic space. As such, 'creat[ing] spaces' for other kinds of reading practices, while possible, is difficult in that spaces are neither constant nor predictable. As Smith notes (2017), feminist considerations of gender and spatiality must account for classroom spaces as agentive forces, where the classroom as an "active body" (Dernikos, 2018) and the "things" with/in it "can support or queer/challenge gender roles depending on temporal material-discursive conditions" (p. 1). Within this next section, I examine how literacy learning in Ms. Rizzo's class also involved the affective force of allure. Specifically, I map out how thinking with allure enabled me to sense the emergence of new forms of gendered and literate subjectivities with/in classroom spaces, in ways that both challenged and affirmed the forces of heteronormativity.

Within Ms. Rizzo's first grade classroom, the production of masculinities and femininities within given spaces shifted, depending on students' intimate attachments to particular bodies and things. These shifts soon caught Ms. Rizzo's attention as well as my own, as they now enabled many boys to openly read London's princess books.

\section{Readers Workshop in session}

Ms. Rizzo: Nice work table 6. I like the way Peter is reading quietly. . .

As Ms. Rizzo's voice trails off, my visual gaze is instantly directed towards Peter's physical body. I immediately see Peter sitting upright, eyes focused-almost mesmerized-by the book he is reading, Disney's Snow White. Snow White happens to be one of the many books London donated to the classroom - one that, just a few weeks ago, Peter claimed 'no way I'm reading that.' I begin to feel surges of astonishment and delight rise up in me, as I turn towards Ms. Rizzo.

Miss Bessie: Did you notice what Peter is reading?

Ms. Rizzo: You know what I realized the other day - that the books London donated were not in the leveled baskets where I had put them. They somehow ended up in the center baskets on tables. London is very popular with boys and girls, so I'm thinking that's why everyone wants to read them.

While all girls could, at one time or another, be spotted reading London's books, only a few boys had dared to choose them as reading material (e.g. Alim). In fact, many of the hegemonic male students openly rejected them, causing other males to question reading them (e.g. Alim), read them secretly (e.g. Dylan), or avoid them altogether (e.g. Austin, Peter). You could imagine my surprise, then, when I saw Peter embracing the Snow White text.

Peter: Miss Bessie, I really like this book. (shows it to me, see Figure 2)

Miss Bessie: I remember you saying you wouldn't read a book like this one (a "girls' book"). You changed your mind? 
Peter: I didn't really look in it and that's why I said I hate it. . now I like it. I changed my mind because of what's on the inside. (points to "Princess London," see Figure 4)

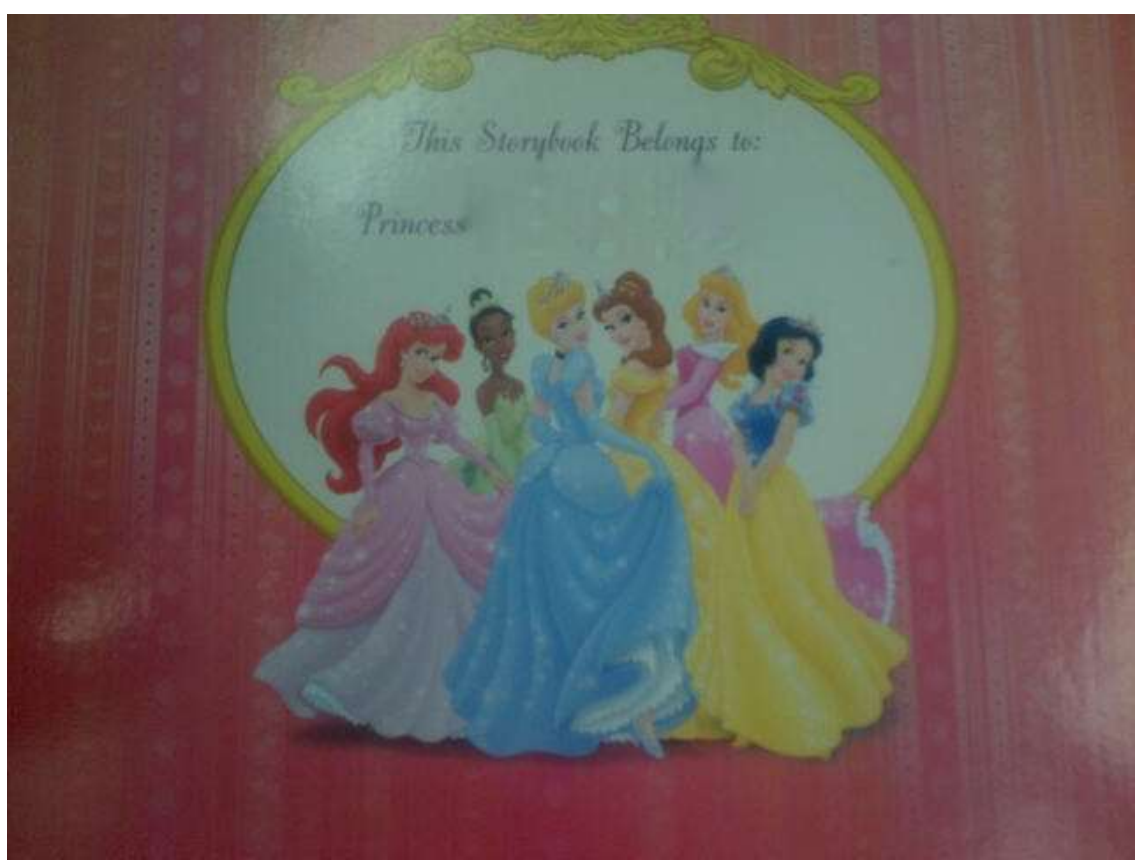

Figure 4. Princess London²

Miss Bessie: Because of London? (He nods)

Peter: Yeah, I like it because it's London's.

Peter: (points to Snow White) She's nice and kind and beautiful. (Peter looks at London who is secretly putting on lip gloss)

Peter: Just like London.

Miss Bessie: I didn't know you liked London.

Peter: Yeah, I been loving London-way before Austin.

Initially, Peter regarded Snow White as a book for girls. However, as noted in the introduction, it now seems that this text has morphed into something else-a thing attached to London's very body, yet in ways that now intensify Peter's captivation with London as a young girl and potential love interest. Peter admits that he's 'been loving London' and now 'likes' this book because of what's on the inside: London's name, which here linguistically transforms her into one of many Disney fairytale princesses (Princess London). London's body seems to have extended into the book Snow White in order to establish alluring "human-nonhuman fields of captivation" (Thrift, 2008. p. 9) for Peter, which, in turn,

\footnotetext{
${ }^{2}$ Actual name of "Princess" [London] blurred for confidentiality purposes.
} 
create possibilities for him to become a "good reader" who now enjoys the pleasure that comes from being linked to a text that enables his body and London's to be "merged" together. Thus, Peter magically becomes part of a series of fractal bodies which opens up new social worlds for him (Thrift, 2008).

More specifically, allure produces a kind of intimacy that provides associations and dissociations as well as stimulates imagination and enjoyment (Thrift, 2008). In other words, this affective encounter enables Peter to now see/feel London in the text, as well as in the character Snow White, which opens up space for him to now see himself reading it. For Peter, Snow White in many ways has taken on a life of her own-here a living thing, who is not quite London but is nevertheless 'nice and kind and beautiful.... just like London.' And it is his fascination with both London and Snow White that enables him (at least momentarily) to not only feel connected to London but also to "magically" become a part of her, so much so that he is now able to enjoy a book that he once classified as 'ugh...girly.'

As Berlant (1998) argues, intimacy emerges from mobile processes of attachment that drive us toward something like "a kind of wild thing" (p. 284). Here, this drive creates spaces for different becomings (Deleuze \& Guattari, 1987). These moments with Peter show us how "what was considered as alive can become thing-like and what was considered as dead is able to show signs of life" (Thrift, 2008, p. 13). Because Snow White as book and London as human being now have a kind of "uncertain status" (Thrift, 2008 , p. 13) they are both able to captivate Peter, arouse his interest in fairytales, and stimulate his curiosity for those texts that he once denigrated. This magical attachment to Snow White/London is redefined simultaneously as a positive attachment to reading that has its own 'intrinsic value' (Thrift, 2008). Peter's affective captivation with London moves him to read a 'girls' book' without fear of social ridicule and, academically, his intense interest in reading Snow White and London's other donated books serves to trouble his status as a "struggling reader." In fact, many of London's donated books, including Snow White, were technically above Peter's reading level, and yet Peter did not seem to have any difficulty decoding or comprehending them. Overall, I would like to suggest that reimagining literacy learning as alluring here opens us space to think about how the circulation of affect (e.g. love) accumulates value for young boys socially and psychically. It also moves us into thinking about new ways to consider gender as well as literacy, where allure might allow for other ways of "doing boy" (see also Reeser \& Gottzén, 2018) and viewing the subject positions of "good" and "struggling" reader.

\section{The Affective Contagion of 'Girls' Books'}

Soon, Peter's interactions with London's texts functioned as a kind of contagion, where other boys, such as Austin, chose to read London's donated books. 


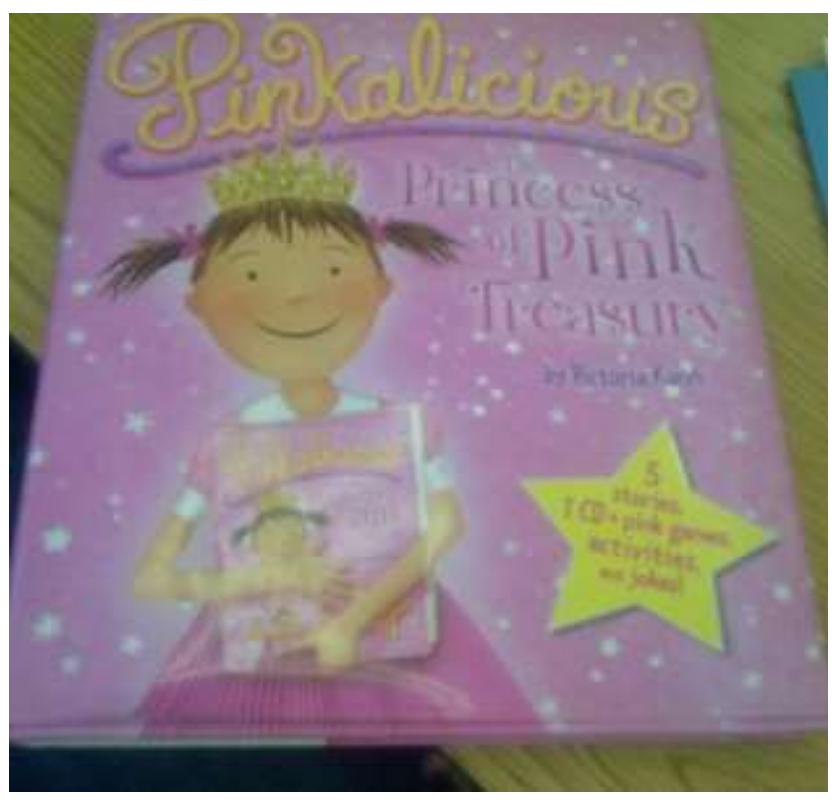

Figure 5. Pinkalicious: One of London's donated books

Austin: I love Pinkalicious.

Dan: What?

Beth: He likes it because it's London's books.

Dan: Oh brother.

Austin: But I hate Barbie!

Natasha: I like Pinkalicious-it's my favorite.

Austin: Me too.

Tom: I love pink.

Natasha: Pink is for girls.

Tom: No. (his face drops as if he seems hurt by Natasha's words)

Austin: Well, I love pink.

Tom: Me too!

Austin: Because I love London.

With one simple word ('What'), Dan's questioning tone and facial grimace seemed to ring out: "What are you reading that for?" Picking up on Dan's embodied movements, Beth intervenes to suggest that Austin's reading of Pinkalicious is not strange or "abnormal" because the book belongs to London. When it came to London's donated books, many of Ms. Rizzo's students began to momentarily shift their binary views on girls' and boys' books. For boys, reading these books soon became an acceptable way to bond with London. Or, perhaps, it operated as an attention-seeking technology (Alvermann \& Eakle, 2007): a bid for London's attention in a place (Ms. Rizzo's classroom) where attention was often regulated and territorialized (e.g., students were expected to "still" their "noisy bodies" in order to read silently). Specifically, for Austin, it served as a way to express his captivation with London-a girl whom 
he 'love[d].' As Thrift notes, allure makes it possible for objects to provide messages that function to create new aesthetic norms, where "affective devices...are now able to be introduced into these worlds in ways that would have been difficult before" (p. 13). Similar to Peter, this passion for London now moved Austin to be affectively attached to London's 'fractal' body, as well as engaged with different kinds of text. It positioned him in such a way that allowed him to not only openly express his 'love' for London but also share his excitement over a once "taboo" book that was initially coded as feminine.

That said, within this scene we also see that these new norms are still subject to processes of reterritorialization, in ways that invoke a kind of symbolic violence. Austin, perhaps sensing that his status as a proper boy may be at risk here, quickly interjects by adding that while he loves London's books, he hates Barbie, "the quintessential icon of American femininity" (Forman-Brunell, 2009, p. 305). Interestingly, it is Natasha who attempts to police the gender order here. Her words ('pink is for girls') serve as a linguistic insult operating to contain (Chen, 2012) the gender order by potentially shaming Tom into being a "proper boy" (Connell, 1996)-i.e., one who does not 'love' pink and is, therefore, normatively masculine. Austin again reclaims his position as a heteronormative male by connecting his love for London to both his desire to read Pinkalicious and his love for the color pink: 'I love pink. . . because I love London.' According to Thrift, one specific style of allure is that subjects and objects blur into one another in ways that produce an "object effect: an object standing for a world without troubles...these ideals can be glimpsed in the imaginary realm" (p. 14). Thus, in an affective world where Austin is intimately connected to London and the texts associated with her personhood, he can ideally navigate the binary logic of gendered books to trouble the belief that certain books as well as colors are for girls only.

At the same time, these new possibilities for Austin as a more-than-human subject become entirely dependent on those bodies with which he forms an affective assemblage. Unlike in the case of Peter, here Dan and Natasha offer a challenge to the possibility of different gendered and literate subjectivities. In order for Austin to retain his popularity/social status and, at the same time, continue to like "girly stuff" he must profess his love for London-note when Tom does not do so, how he is shamed. However, Austin must simultaneously denigrate what he believes to be a symbol of femininity, namely the fashion doll Barbie. There seems to be something about femininity as a force-relation that threatens Austin's sense of what it means to be a boy (his masculinity), causing him to both purposefully denigrate and distance himself from the figure of Barbie. What is perhaps most "alluring" about this moment, then, is that for Austin "doing boy" here involves both actively embracing and repudiating "girl."

Interestingly enough, Austin later revealed to me that his feelings about Barbie were "fake", as he didn't really hate her. He also admitted that he liked Pinkalicious and had "read it before [London]." According to Thrift, one of the hallmarks of allure is that it may involve manipulation and certain forms of deception that must go unnoticed. In other words, for something to remain alluring, "it must appear as effortless" (p. 15), and the way to accomplish that is for the subject to "edit out discordant details that could break the spell" (p. 15). Austin first does so by suggesting that his pleasure derives from his love of 
London and not some innate predilection for "girls' stuff," and secondly by openly stating he "hates Barbie' in order to re/assert his "manliness." Thus, even as literacy learning produced both excitement and bliss for young boys, such as Peter and Austin, and made new subjectivities possible, the heterosexual matrix continued to flow through classroom spaces in unpredictable ways, serving to territorialize (e.g., girls' books as taboo for boys), deterritorialize (e.g., boys openly reading girls' books by aligning themselves with London), and reterritorialize bodies, spaces, and things (e.g., Austin's safeguarding his desires by aligning himself with London's female body and distancing himself from Barbie).

\section{Literacy Learning as Alluring: A Matter of Ethical Response-ability}

Contrary to the ubiquitous narrative of failing schools, failing boys, and literacy crises (see Ringrose, 2013; Weaver-Hightower, 2009), gender and student achievement cannot be adequately understood through decontextualized literacy and gender debates that dichotomously position all girls as successful and all boys as failing (see also Pomerantz \& Raby, 2018 for a discussion of "smart girlhood"). Within Ms. Rizzo's first grade classroom, the de/re/territorialization of bodies, spaces, and things highlights how subjectivities constantly emerge in relation to complex affective assemblages that are always contingent upon the "shifts and flows of human and non-human bodies" (Smith, 2017, p. 6). While boys of color, such as Peter and Dylan, were regarded as struggling readers, such labels do not account for (a) the multiple, shifting ways boys and girls performed their gendered and literate identities, (b) how students extended relationally into other human and nonhuman bodies, and (c) how the forces of gender, sexuality, and race functioned to animate (e.g., Peter's body in relation to London and her texts) and deflate bodies (e.g., Austin denigrating Barbie to assert his masculinity) in myriad ways, thereby becoming a source of possibility and/or "major risk to the subject's integration and social functioning" (Renold \& Mellor, 2013, p. 37).

Within these moments, I have tried to show that we cannot begin to explore "literacy" without mapping out its affective entanglements with gender, sexuality, race, and other relational forces. An attention to literacy learning as alluring enables educators to better sense how becoming an unsuccessful and/or successful literacy learner is an affective encounter that is tenuously constituted in space and time (Leander \& Rowe, 2006). More specifically, a theory of allure helps us consider how learning to read is a "series of overlapping affective fields" (Thrift, 2008, p. 21), where alluring texts/bodies circulate in all kinds of ways to make new gendered and literate subjectivities possible (e.g., Peter is momentarily able to "do boy" differently and become a "good reader") and/or impossible for young children (e.g., Austin simultaneously embraces and repudiates that which is "feminine").

Although allure circulates in unpredictable ways that can never be fully captured or contained, I would nevertheless like to invite educators to attempt to tune into it as an agential force so that we may begin to aesthetically modulate (Thrift, 2008) the narrative fictions that have come to dominate literacy and gender debates for the past 20 years. While I have explored how allure can, at times, reaffirm hegemonic gender relations and therefore promote a kind of symbolic violence, I would like to raise the 
possibility that allure can also do some-thing to literacy and gender that feels much more hopeful (see Reeser \& Gottzén, 2018 for discussion on affect and masculinity). In the words of Lauren Berlant (1998), collective scenes are intimate spaces and "intimacy builds worlds" (p. 282). If allure momentarily opens up intimate spaces to consider new and different ways to think about gender and literacy, and the "doing" of boy and/or girl, I wonder: What kind of collective and personal future possibilities can we imagine once gender and sexuality are no longer bound to a stabilizing narrative (Berlant, 1998)? And how might these possibilities create new worlds that disrupt the normalizing of particular knowledges, subjectivities, and institutional practices? For me, such questions feel hopeful, as they highlight how the past/present/future and who students may become as literate and gendered subjects are neither fixed nor set in stone. Rather, they are "always being reworked" (Dolphijn \& van der Tuin, 2012, p. 68), where agency and subjectivity emerge not as a singular entity but "possibilities for worldly re-configurings" (p. 55).

These 're-configurings' involve an ethics of relationality (Braidotti, 2006) or response-ability (Barad, 2007), that is, the understanding that we are all inextricably connected to everybody and everything around us - both human and nonhuman (Deleuze \& Guattari, 1987; Leander \& Rowe, 2006). As Barad argues:

Ethics is about mattering, about taking account of the entangled materializations of which we are part, including new configurations, new subjectivities, new possibilities. Even the smallest cuts matter. Responsibility, then, is a matter of the ability to respond. Listening for the response of the other and an obligation to be responsive to the other, who is not entirely separate from what we call the self. This way of thinking ontology, epistemology, and ethics together makes for a world that is always already an ethical matter. (Dolphijn \& van der Tuin, 2012, p. 69)

In the end, I would like to suggest that attending to literacy learning as alluring entails a more relational and ethical 'response' to current literacy and gender debates. Allure does so by repositioning literacies/literacy learning as human and nonhuman fields of captivation: as agential, entangled, affective, and altogether magical processes. Imagining literacy learning in any other way may very well be cruel (Berlant, 2011; see also Dernikos \& Thiel, 2019), as it ignores "a theory of action and responsibility that crosses the human-nonhuman divide" (Bennett, 2010 p. 24), a theory which attends to bodies of all kinds as vital-even bewitching-force-relations. Ultimately, by complicating the very notion of successful literacy learners/literacy failures (Skelton \& Francis, 2011), allure makes it impossible for students to bear full responsibility for the conditions of possibility that have produced them as successful and/or failing and offers up other ways to imagine students' subjectivities and social worlds - ways that we may never fully understand but, nevertheless, matter. 


\section{Acknowledgements}

I would like to thank Nancy Lesko and Janet Miller for inspiring this work. I am also grateful to the reviewers and editors for their thoughtful suggestions.

\section{References}

Ahmed, S. (2004). Collective feelings or, the impressions left by others. Theory, Culture, and Society, 21(2), 25-42. https://doi.org/10.1177/0263276404042133

Alvermann, D. E., \& Eakle, J. (2007). Dissolving learning boundaries: The doing, redoing, and undoing of school. International Handbook of Student Experience in Elementary and Secondary School, 143166. https://doi.org/10.1007/1-4020-3367-2_6

Barad, K. (2007). Meeting the universe halfway: Quantum physics and the entanglement of matter and meaning. Durham, NC: Duke University Press. https://doi.org/10.1215/9780822388128

Berlant, L. (1998). Intimacy: A special issue. Critical Inquiry, 24(2), 281-288. https://doi.org/10.1086/448875

Berlant, L. (2011). Cruel optimism. Durham, NC: Duke University Press. https://doi.org/10.1215/9780822394716

Bennett, J. (2010). Vibrant matter: A political ecology of things. Durham, NC: Duke University Press. https://doi.org/10.1215/9780822391623

Bissell-Brown, V. (1990). The fear of feminization: Los Angeles high schools in the progressive era. Feminist Studies, 16, 493-518. https://doi.org/10.2307/3178017

Blackman, L. (2012). Immaterial bodies: Affect, embodiment, mediation, Sage, Thousand Oaks. https://doi.org/10.4135/9781446288153

Braidotti, R. (2006). Transpositions: On nomadic ethics. Cambridge, England: Polity Press.

Chen, M.Y. (2012). Animacies: Biopolitics, racial mattering and queer affect. Durham, NC: Duke University Press. https://doi.org/10.1215/9780822395447

Connell, R.W. (1996). Teaching the boys: New research on masculinity, and gender strategies for schools. Teachers College Record, 98(2), 206-234.

Connell, R.W., \& Messerschmidt, J. W. (2005). Hegemonic masculinity: Rethinking the concept. Gender \& Society, 19(6), 829-859. https://doi.org/10.1177/0891243205278639

Davies, B. (1997). Constructing masculinities through critical literacy. Gender and Education, 9(1), 1-27. https://doi.org/10.1080/09540259721420

Deleuze, G., \& Guattari, F. (1987). A thousand plateaus: Capitalism and schizophrenia. Minneapolis, MN: University of Minnesota Press.

Dernikos, B. P. (2018). 'It's like you don't want to read it again': Exploring affects, trauma, and 'willful' literacies. Journal of Early Childhood Literacy, 1-32. https://doi.org/10.1177/146879841875618

Dernikos, B. P., Lesko, N., McCall, S., \& Niccolini, A. (2020). Mapping the affective turn in education: Theory, research, and pedagogy. NY: Routledge. 
Dernikos, B. P., \& Thiel, J. J. (2019). Literacy learning as cruelly optimistic: Recovering possible lost futures through transmedial storytelling. Literacy, 1-9. https://doi.org/10.1111/lit.12207

Dolphijn, R., \& van der Tuin, I. (2012). New materialism: Interviews \& cartographies. Ann Arbor, MI: Open Humanities Press. https://doi.org/10.3998/ohp.11515701.0001.001

Dutro, E. (2001/2002). “But that's a girl's book!” Exploring gender boundaries in children's reading practices. The Research Teacher, 55(4), 376-384.

Dutro, E. (2003). "Us boys like to read football and boy stuff": Reading masculinities, performing boyhood. Journal of Literacy Research, 34(4), 465-500.

https://doi.org/10.1207/s15548430jlr3404_4

Ferguson, A. (2001). Bad boys: Public schools in the making of black masculinity. Ann Arbor, MI: The University of Michigan Press. https://doi.org/10.3998/mpub.16801

Forman-Brunell, M. (2009). Barbie in "life": The life of Barbie. Journal of the History of Childhood and Youth, 2(3), 305-311.

Francis, B., \& Skelton, C. (2005). Reassessing gender and achievement: Questioning contemporary key debates. London, England: Routledge. https://doi.org/10.4324/9780203412923

Frank, B., Kehler, M., Lovell, T., \& Davison, K. (2003). A tangle of trouble: Boys, masculinity a schoolingfuture directions. Educational Review, 55(2), 119-133.

https://doi.org/10.1080/0013191032000072173

Griffin, C. (2004). Good girls, bad girls: Anglocentrism and diversity in the constitution of contemporary girlhood. In A. Harris (Ed.), All about the girl: Culture, power, and identity (pp. 29-43). New York, NY: Routledge.

Grosz, E. (1993). Bodies and knowledges: Feminism and the crisis of reason. In L. Alcoff \& E. Potter (Eds.), Feminist epistemologies (pp. 187-215). New York, NY: Routledge.

Harris, A. (2004). Future girl: Young women in the twenty-first century. New York, NY: Routledge. https://doi.org/10.4324/9780203490198

Harris, S. (2015). Literacy letdown in primary schools.

http://www.dailymail.co.uk/news/article-81287/Literacy-letdown-primary-schools.html. Accessed 13 March 2018

Hughes, C., \& Lury, C. (2013). Re-turning feminist methodologies: From a social to an ecological epistemology. Gender and Education, 25(6), 786-799.

https://doi.org/10.1080/09540253.2013.829910

Jackson, A. Y., \& Mazzei, L. A. (2012). Thinking with theory in qualitative research. New York, NY: Routledge.

Jones, A. (2001). Learning proper masculine pleasure: Santa clauses and teachers. In A. Jones (Ed.), Touchy subject: Teachers touching children (pp. 109-116). Dunedin, New Zealand: Otago University Press.

Jones, S., \& Spector, K. (2017). Becoming unstuck: Racism and misogyny as traumas diffused in the ordinary. Language Arts, 94(5), 302-312.

Kinnunen, T., \& Kolehmainen, M. (2018). Touch and affect. Analysing the archive of touch biographies. Body \& Society, 1-28. 


\section{https://doi.org/10.1177/1357034X18817607}

Kirkland, D. E., \& Jackson, A. (2009). "We real cool”: Toward a theory of black masculine literacies. Reading Research Quarterly, 44(3), 278-297. https://doi.org/10.1598/RRQ.44.3.3

Leander, K., \& Boldt, G. (2013). Rereading “A pedagogy of multiliteracies": Bodies, texts, and emergence. Journal of Literacy Research, 45(1), 22-46. https://doi.org/10.1177/1086296X12468587

Leander, K. M. \& Ehret, C. (Eds.). (2019). Affect in literacy teaching and learning: Pedagogies, politics, and coming to know. New York, NY: Routledge. https://doi.org/10.4324/9781351256766

Leander, K. M., Philips, N. C., \& Taylor, K. H. (2010). The changing social spaces of learning: Mapping new mobilities. Review of Research in Education, 34, 329-394. https://doi.org/10.3102/0091732X09358129

Leander, K. M., \& Rowe, D. W. (2006). Mapping literacy spaces in motion. A rhizomatic analysis of a classroom literacy performance. Reading Research Quarterly, 41(4), 428-460.

https://doi.org/10.1598/RRQ.41.4.2

Lemieux, A. (in press). De/constructing literacies: Considerations for engagement. New York, NY: Peter Lang.

Lenters, K. (2016). Riding the lines and overwriting in the margins: Affect and multimodal literacy practices. Journal of Literacy Research, 48(3), 280-316. https://doi.org/10.1177/1086296X16658982

Lenz Taguchi, H., \& Palmer, A. (2014). Reading a Deleuzio-Guattarian cartography of young girls' "schoolrelated" ill-/well-being. Qualitative Inquiry, 20(6), 764-771. https://doi.org/10.1177/1077800414530259

Lucey, H., \& Walkerdine, V. (2000). Boys' underachievement: Social class and changing masculinities. In T. Cox (Ed.), Combating educational disadvantage (pp. 37-52). New York, NY: Falmer.

Mac an Ghaill, M. (1994). The making of men: Masculinities, sexualities and schooling. Buckingham, England: Open University Press.

MacLure, M. (2013). Classification or wonder? Coding as an analytic practice in qualitative research. In R. Coleman \& J. Ringrose (Eds.), Deleuze and research methodologies (pp. 164-183). Edinburgh, Scotland: Edinburgh University Press.

Martino, W. J. (2008). Male teachers as role models: Addressing issues of masculinity, pedagogy and the re-masculinization of schooling. Curriculum Inquiry, 38(2), 189-223. https://doi.org/10.1111/j.1467-873X.2007.00405.x

McRobbie, A. (2009). The aftermath of feminism: Gender, culture, and social change. London, England: Sage.

McWilliam, E. (1996). Touchy subjects: A risky inquiry into pedagogical pleasure. British Educational Research Journal, 22(3), 305-317. https://doi.org/10.1080/0141192960220304

Messner, M. A. (2002). Taking the field: Women, men, and sports. Minneapolis, MN: University of Minnesota Press.

Mulcahy, D. (2012). Affective assemblages: Body matters in the pedagogic practices of contemporary school classrooms. Pedagogy, Culture and Society, 20(1), 9-27. https://doi.org/10.1080/14681366.2012.649413 
Muñoz, J. E. (2000). Feeling brown: Ethnicity and affect in Ricardo Bracho's the sweetest hangover (and other stds). Theatre Journal, 52(1), 67-79. https://doi.org/10.1353/tj.2000.0020

Niccolini, A. (2016a). Affect. In N. M. Rodriguez, W. J. Martino, J. C. Ingrey, \& E. Brockenbrough (Eds.), Critical concepts in queer studies and education (pp. 1-14). New York: NY: Palgrave Macmillan.

Niccolini, A. (2016b). Animate affects: Censorship, reckless pedagogies, and beautiful feelings. Gender and Education, 28(2), 230-249. https://doi.org/10.1080/09540253.2015.1121205

Niccolini, A., Dernikos, B. P., Lesko, N., \& McCall, S. (2019). High passions: Affect and curriculum theorizing in the present. In C. Hebert, N. A. Fook, A. Ibrahim, \& B. Smith, (Eds.), Internationalizing curriculum studies: Histories, environments, and critiques (pp. 157-175). UK: Palgrave Macmillan. https://doi.org/10.1007/978-3-030-01352-3_10

Oxford Dictionaries. (n.d.). Allure. Retrieved from: https://en.oxforddictionaries.com/definition/allure

Pomerantz, S., \& Raby, R. (2018). Bodies, hoodies, schools, and success: Post-human performativity and smart girlhood. Gender and Education. https://doi.org/10.1080/09540253.2018.1533923

Puar, J. K. (2011). "I would rather be a cyborg than a goddess": Becoming-intersectional in assemblage theory. PhiloSOPHIA, 2(1), 49-66.

Ramazanoglu, C., with Holland, J. (2002). Feminist methodology: Challenges and choices. London, England: Sage. https://doi.org/10.4135/9781849209144

Reeser, T. W., \& Gottzén, L. (2018) Masculinity and affect: New possibilities, new agendas. NORMA, 13 (3-4), 145-157. https://doi.org/10.1080/18902138.2018.1528722

Renold, E. (2004). "Other" boys: Negotiating non-hegemonic masculinities in the primary school. Gender and Education, 16(2), 247-265. https://doi.org/10.1080/09540250310001690609

Renold, E., \& Mellor, D. (2013). Deleuze and Guattari in the nursery: Towards an ethnographic multisensory mapping of gendered bodies and becomings. In R. Coleman \& J. Ringrose (Eds.), Deleuze and research methodologies (pp. 23-41). Edinburgh, Scotland: Edinburgh University Press.

Ringrose, J. (2011). Beyond discourse? Using Deleuze and Guattari's schizoanalysis to explore affective assemblages, heterosexually striated space, and lines of flight online and at school. Educational Philosophy and Theory, 43(6), 598-618. https://doi.org/10.1111/j.1469-5812.2009.00601.x

Ringrose, J. (2013). Postfeminist education? Girls and the sexual politics of schooling. New York, NY: Routledge. https://doi.org/10.4324/9780203106822

Sedgwick, E. K. (2003). Touching feeling: Affect, pedagogy, performativity. Durham, NC: Duke University Press. https://doi.org/10.1215/9780822384786

Seigworth, G. (2017). Capaciousness. Capacious: Journal for Emerging Affect Inquiry 1(1), pp. i-v. https://doi.org/10.22387/CAP2017.7

Seigworth, G., \& Gregg, M. (2010). An inventory of shimmers. In M. Gregg \& G. Seigworth (Eds.), The affect theory reader (pp. 1-25). Durham, NC: Duke University Press.

Skelton, C., \& Francis, B. (2009). Feminism and 'the schooling scandal.' New York, NY: Routledge. https://doi.org/10.4324/9780203884331 
Skelton, C., \& Francis, B. (2011). Successful boys and literacy: Are "literate boys" challenging or repackaging hegemonic masculinity? Curriculum Inquiry, 41(4), 456-479. https://doi.org/10.1111/j.1467-873X.2011.00559.x

Smith, J. (2017). Objects of conflict: (Re)configuring early childhood experiences of gender in the preschool classroom. Gender and Education. https://doi.org/10.1080/09540253.2017.1332343

Smith, S. (2004). The nonfiction reading habits of young successful boy readers: Forming connections between masculinity and reading. Literacy, 10-15. https://doi.org/10.1111/j.00340472.2004.03801003.x

Stewart, K. (2007). Ordinary affects. Durham, NC: Duke University Press. https://doi.org/10.1215/9780822390404

Taft, J. K. (2004). Girl power politics: Pop-culture barriers and organizational resistance. In A. Harris (Ed.), All about the girl: Culture, power, and identity (pp. 69-78). New York, NY: Routledge.

Taylor, C. (2013). Objects, bodies, and space: Gender and embodied practices of mattering in the classroom. Gender and Education, 25(6), 688-703. https://doi.org/10.1080/09540253.2013.834864

Thiel, J. (2015). “Bumblebee's in trouble!” Embodied literacies during imaginative superhero play. Language Arts, 93(1), 38-49.

Thrift, N. (2008). The material practices of glamour. Journal of Cultural Economy, 1(1), 9-23. https://doi.org/10.1080/17530350801913577

Walkerdine, V. (1990). Schoolgirl fictions. London, England: Verso.

Wargo, J. M. (2018). Writing with wearables? Young children's intra-active authoring and the sounds of emplaced invention. Journal of Literacy Research, 1-22. https://doi.org/10.1177/1086296X18802880

Weaver-Hightower, M. (2003). The "boy turn" in research on gender and education. Review of Educational Research, 73(4), 471-498. https://doi.org/10.3102/00346543073004471

Weaver-Hightower, M. B. (2009). Issues of boys' education in the United States: Diffuse contexts and futures. In W. Martino, M. Kehler, \& M. B. Weaver-Hightower (Eds.), The problem with boys' education: Beyond the backlash (pp. 1-35). New York, NY: Routledge.

Vannini, P. (2015). Enlivening ethnography through the irrealis mood: In search of a more-thanrepresentational style. In P. Vannini (Ed.), Non-representational methodologies: Re-envisioning research (pp. 112-129). New York, NY: Routledge. https://doi.org/10.4324/9781315883540

Wetherell, M. (2013). Affect and discourse - What's the problem? From affect as excess to affective/discursive practice. Subjectivity, 6(4), 349-368. https://doi.org/10.1057/sub.2013.13 